\title{
Association of prepartum lying time with nonesterified fatty acids and stillbirth in prepartum dairy heifers and cows
}

\author{
B. T. Menichetti, ${ }^{1}$ J. M. Piñeiro, ${ }^{1 *} \odot$ A. A. Barragan, ${ }^{1} \dagger \odot$ A. E. Relling, ${ }^{2} \odot$ A. Garcia-Guerra, ${ }^{3} \odot$ \\ and G. M. Schuenemann ${ }^{1} \ddagger$ (D) \\ ${ }^{1}$ Department of Veterinary Preventive Medicine, The Ohio State University, Columbus 43210 \\ ${ }^{2}$ Department of Animal Sciences, The Ohio State University, Wooster 44691 \\ ${ }^{3}$ Department of Animal Sciences, The Ohio State University, Columbus 43210
}

\begin{abstract}
The objective of the present study was to assess the association of prepartum lying time (LT) and the coefficient of variation $(\mathrm{CV})$ of LT within $7 \mathrm{~d}$ before calving with prepartum serum nonesterified fatty acid (NEFA) concentration at $7 \pm 3 \mathrm{~d}$ prepartum (dpp) and stillbirth. Prepartum pregnant Holstein heifers and cows from 3 dairy herds were used $(\mathrm{n}=1,044)$. Animals were housed in freestall barns using a prepartum pen $21 \mathrm{~d}$ before the expected calving date and were moved into a contiguous maternity pen at parturition. Monthly, cohorts of 20 to 36 animals (heifers and cows combined) were enrolled at each farm and electronic data loggers (IceQube, IceRobotics, Edinburgh, UK) were fitted to the hind leg of individual animals to assess their behavioral activity. Stillbirth was defined as a calf born dead or died during the first $24 \mathrm{~h}$ after parturition in dams with normal gestation length. The LT was recorded for the last $7 \mathrm{dpp}$ to assess differences among dams with stillbirth versus those with a calf born alive. Mean LT within $7 \mathrm{~d}$ before blood NEFA collection was assessed to determine the association with prepartum serum NEFA at $7 \pm 3$ dpp. Blood samples for the assessment of serum NEFA concentration were collected from prepartum animals at $14 \pm 3$ and at $7 \pm 3 \mathrm{dpp}$. Blood samples for total serum calcium concentration were collected from postpartum cows within $48 \mathrm{~h}$ after parturition to assess differences among cows with stillbirth versus those with a calf born alive. Data were analyzed using CORR, MIXED, or GLIMMIX procedures of SAS (SAS Institute Inc., Cary, NC). Dams
\end{abstract}

Received April 1, 2020.

Accepted August 7, 2020.

*Current address: Texas A\&M AgriLife Research and Extension Center, Amarillo, TX 79106.

†Current address: Department of Veterinary and Biomedical Sciences, Pennsylvania State University, University Park 16802.

$\ddagger$ Corresponding author: schuenemann.5@osu.edu experiencing dystocic births had a greater proportion of stillbirth, but herd, parity, and season did not have an effect. Dams with a stillborn calf had reduced LT and increased CV of LT within the last $7 \mathrm{dpp}$ compared with dams with a calf born alive, regardless of parity. Multiparous cows with a stillborn calf had higher prepartum serum NEFA concentration compared with multiparous cows with a calf born alive, but this did not differ for first-calf heifers. Regardless of parity, the proportion of postpartum cows with hypocalcemia was higher for dams with a stillborn calf compared with those with a calf born alive. Regardless of parity, LT of prepartum dams was strongly correlated with the CV of LT (as LT increased, the CV decreased), and prepartum dams with a mean LT between 11 and $15 \mathrm{~h} / \mathrm{d}$ had the lowest serum NEFA concentration compared with dams with LT of 8 to 10 or $>16 \mathrm{~h} / \mathrm{d}$. Serum NEFA concentrations at $7 \pm 3$ dpp was positively correlated with the CV of LT within $7 \mathrm{~d}$ before blood sample. These results show that the dam's prepartum LT and its consistency over time are associated with prepartum serum NEFA and calf survival at calving.

Key words: stillbirth, lying time, nonesterified fatty acids, dairy cattle welfare

\section{INTRODUCTION}

Stillbirth is defined as a calf born dead or that dies within the first $24 \mathrm{~h}$ of birth (Philipsson et al., 1979; Schuenemann et al., 2011). It is common to observe great variation in stillbirth within and between dairy herds (Philipsson et al., 1979). The time around $3 \mathrm{wk}$ before and after parturition (Grummer, 1995) is critical for the life of the dam and their offspring. For any dairy operation, calving is an essential requirement of the production system in which cows initiate lactation and provide the future replacements of the herds. Several risk factors such as dystocia (Berry et al., 2007; Lombard et al., 2007), parity of the dam (Gundelach et al., 2009), calving season (Meyer et al., 2001; Silva del 
Río et al., 2007), and dairy personnel (Lombard et al., 2007; Schuenemann et al., 2011) were associated with increased proportion of stillbirth. However, risk factors affecting stillbirth vary from farm to farm, and blanket recommendations often fail when applied to a variety of different herds.

Although lying time (LT) varies according to the stage of lactation and age of animals, lactating dairy cows have a strong behavioral need to rest (lying down) for approximately $12 \mathrm{~h} / \mathrm{d}$ (Krohn and Munksgaard, 1993; DeVries and von Keyserlingk, 2005; Jensen et al., 2005). Moreover, lactating dairy cows choose resting over eating when the opportunity to perform these behaviors is limited (Munksgaard et al., 2005). During the last few years, the availability of monitoring devices such as accelerometer data loggers have increased. These devices are capable of monitoring behavioral activity in dairy cattle such as LT (Martiskainen et al., 2009; Vázquez Diosdado et al., 2015), estrus detection in reproductive programs (Rorie et al., 2002), as well as health events of lactating cows (e.g., health and digestive disorders; Stangaferro et al., 2016). Using this technology to monitor cow behavior may provide critical information for dairy producers to make meaningful management adjustments. Prepartum animals are exposed to many physiological adaptations and farm management factors including dietary changes, vaccination, and weekly pen changes as well as monitoring of urine $\mathrm{pH}$ during the last $3 \mathrm{wk}$ before parturition. All of these factors may serve as stressors that negatively affect the capability of pregnant dams to maintain homeostasis (including meeting their LT requirements) and DMI, leading to an increase in blood nonesterified fatty acid (NEFA) before calving (Piñeiro et al., 2019a). Furthermore, restricting LT modifies the behavior of cows at the feed bunk by reducing feeding time in favor of LT (Munksgaard et al., 2005). The goal of prepartum nutrition is to just meet the nutrient requirements for prepartum dams during the last couple of weeks before calving (Dann et al., 2006; Drackley and Cardoso, 2014). Because the process of parturition requires energy and calcium for abdominal and uterine contractions, changes in LT patterns of prepartum pregnant dams may serve as a leading management indicator to reduce elevated serum NEFA and stillbirth at caving.

Therefore, the objective of the present study was to assess the association of prepartum LT and the coefficient of variation $(\mathbf{C V})$ of LT within $7 \mathrm{~d}$ before calving with prepartum serum NEFA concentration at $7 \pm 3 \mathrm{~d}$ prepartum (dpp) and stillbirth. We hypothesized that reduced daily $\mathrm{LT}$ and increased $\mathrm{CV}$ of $\mathrm{LT}$ in prepartum dams (first-calf heifers and multiparous cows) would be associated with increased prepartum serum NEFA and calf mortality at calving (stillbirth).

\section{MATERIALS AND METHODS}

\section{Animals and Facilities}

A total of 1,051 pregnant Holstein dams (401 firstcalf heifers and 650 multiparous cows) from 3 Ohio dairy herds were enrolled (herd $1=1,300$ cows, herd 2 $=1,500$ cows, and herd $3=2,700$ cows) in this prospective observational study. Briefly, in 2 of the dairy farms, first-calf pregnant heifers and multiparous cows were comingled during the prepartum period and housed in 6-row freestall barns with deep sand bedding. Cows from these 2 farms were fed once daily in the afternoon. In the third herd, pregnant heifers and multiparous cows were grouped in 2 separate prepartum pens, and animals were housed in 4-row freestall barns with deep recycled manure bedding. Cows from the third farm were fed twice daily, in the morning and afternoon. In addition, dairy heifers and cows were fed a TMR to meet or exceed dietary nutritional requirements (NRC, 2001; Table 1). This study was conducted from August

Table 1. Ingredients and nutrient composition of prepartum diets by herd (DM basis)

\begin{tabular}{|c|c|c|c|}
\hline Item & Herd 1 & Herd 2 & Herd 3 \\
\hline \multicolumn{4}{|l|}{ Ingredient (\%) } \\
\hline Grass hay & - & 14.9 & - \\
\hline Wheat straw & 26.3 & 31.7 & 32.1 \\
\hline Canola meal light & 14.1 & - & - \\
\hline Corn silage & 48.9 & 28.0 & 31.8 \\
\hline Grain mix & - & - & 8.1 \\
\hline Mineral/vitamin mix & 7.4 & 2.0 & 5.9 \\
\hline Soybean meal & - & 4.7 & 8.3 \\
\hline Distiller grains & - & 11.2 & 7.2 \\
\hline Fruit waste & - & 4.7 & - \\
\hline Beet pulp & - & - & 5.0 \\
\hline Bypass proteins and AA & - & - & 1.6 \\
\hline \multicolumn{4}{|l|}{ Nutrient profile } \\
\hline $\mathrm{NE}_{\mathrm{L}}(\mathrm{Mcal} / \mathrm{kg})$ & 1.34 & 1.50 & 1.43 \\
\hline $\mathrm{CP}(\%)$ & 15.40 & 12.35 & 16.90 \\
\hline $\operatorname{NDF}(\%)$ & 44.12 & 45.53 & 44.69 \\
\hline $\operatorname{ADF}(\%)$ & 29.80 & 31.56 & 28.50 \\
\hline Starch $(\%)$ & 17.59 & 14.74 & 14.67 \\
\hline $\mathrm{Ca}(\%)$ & 1.46 & 0.47 & 1.38 \\
\hline $\mathrm{P}(\%)$ & 0.35 & 0.28 & 0.35 \\
\hline $\mathrm{Mg}(\%)$ & 0.39 & 0.26 & 0.46 \\
\hline $\mathrm{K}(\%)$ & 1.38 & 1.07 & 1.05 \\
\hline $\mathrm{Na}(\%)$ & 0.07 & 0.10 & 0.21 \\
\hline $\mathrm{Cl}(\%)$ & 0.85 & 0.48 & 0.70 \\
\hline $\mathrm{S}(\%)$ & 0.47 & 0.31 & 0.41 \\
\hline $\mathrm{DCAD}^{1}(\mathrm{mEq} / 100 \mathrm{~g}$ of $\mathrm{DM})$ & -15.23 & -1.76 & -9.00 \\
\hline
\end{tabular}

${ }^{1}$ Dietary cation-anion difference was calculated as follows: DCAD = $(\mathrm{mEq}$ of $\mathrm{Na}+\mathrm{mEq}$ of $\mathrm{K})-(\mathrm{mEq}$ of $\mathrm{S}+\mathrm{mEq}$ of $\mathrm{Cl})$. The water contribution of $\mathrm{Na}(6.72 \mathrm{mg} / \mathrm{kg}), \mathrm{K}(<1 \mathrm{mg} / \mathrm{kg}), \mathrm{Cl}(14.5 \mathrm{mg} / \mathrm{kg})$, and $\mathrm{S}(10 \mathrm{mg} / \mathrm{kg}$ ) was considered for the DCAD (Cumberland Valley Analytical Service, Hagerstown, MD). 
2016 through December 2017. All procedures described below were reviewed and approved by The Ohio State University Institutional Animal Care Use Committee.

\section{Management of Prepartum Dams and Calving}

Monthly, cohorts of 20 to 36 animals, pregnant heifers and cows combined, were enrolled at each farm for a 1-yr period. Farms were visited twice weekly. A list of prepartum heifers and cows was obtained a $28 \pm$ 3 d before expected parturition date using on-farm computer records (Dairy Comp 305, Valley Agricultural Software, Tulare, CA). Pregnant cows (lactation $\geq 1$; cows) were dried off $60 \pm 3 \mathrm{dpp}$ and moved into the far-off dry pen immediately after last milking. In 2 dairy operations, pregnant heifers (lactation $=0$ ) were moved into the same far-off pen with pregnant cows at $60 \mathrm{dpp}$ and then moved into prepartum pen at 21 dpp. In the third dairy herd, pregnant heifers arrived at the farm approximately $30 \mathrm{dpp}$ where pregnant cows and heifers were housed in 2 separated prepartum pens. Stoking density was assessed once per week during the entire length of the study by counting the number of animals within a pen and diving by the number of stalls available.

All heifers and cows were moved into an adjacent individual or group maternity pen for parturition. Prepartum animals were monitored by on-farm personnel for imminent signs of parturition every $1 \mathrm{~h}$ (appearance of the feet of the calf outside the vulva or appearance of amniotic sac; Schuenemann et al., 2011). The calving ease of cows (assistance provided at birth) were recorded by on-farm personnel using a 4-point scale ( 1 = no assistance provided; $2=$ light assistance by one person without the use of mechanical traction; $3=$ mechanical extraction of the calf with an obstetric calfpuller; and $4=$ severe dystocia: surgery or fetotomy needed; Schuenemann et al., 2011). Gestation length of prepartum Holstein dairy heifers and cows were classified as average $($ mean $=276 \mathrm{~d}$ with a population mean $\pm 1 \mathrm{SD}$; range 270 to $283 \mathrm{~d}$ ), short (mean $=262 \mathrm{~d}$ with $\pm 1 \mathrm{SD}$; range 255 to $269 \mathrm{~d}$ ), or long (mean = 290 with $\pm 1 \mathrm{SD}$; range 284 to $297 \mathrm{~d}$ ). Body condition scores and locomotion score (LS) of all animals were assessed at enrollment (14 $\pm 3 \mathrm{dpp})$ using a 5-point scale with 0.25-unit increments (Ferguson et al., 1994). Furthermore, LS was assessed using a 3-point scale with a 1 -unit increment (LS; $1=$ sound, $2=$ mildly lame, $3=$ moderately to severely lame; as described by Amory et al., 2006). Calf sex (male or female) and birth of twins were recorded. After calving, cows were milked to harvest colostrum and moved into the postpartum pen, and calves were moved into straw-bedded hutches. All live-born calves were identified with ear tags, fed colostrum $(3.8 \mathrm{~L})$, and the navel was disinfected with a $7 \%$ iodine solution within $3 \mathrm{~h}$ after birth.

\section{Assessment of NEFA and Calcium of Dams}

Blood samples $(8.0 \mathrm{~mL})$ were collected by coccygeal venipuncture (BD Vacutainer, Franklin Lakes, NJ) weekly until calving. Once calving dates were confirmed, blood samples at $14 \pm 3$ and at $7 \pm 3 \mathrm{dpp}$ were used for the assessment of total serum NEFA concentration. Blood samples for the assessment of total serum calcium were collected within $48 \mathrm{~h}$ after calving. Briefly, blood samples were centrifuged at $3,100 \times g$ for $15 \mathrm{~min}$ at room temperature within $1 \mathrm{~h}$ after collection, and serum samples were stored at $-20^{\circ} \mathrm{C}$ until assayed for total NEFA and calcium.

Serum NEFA concentration was assessed with the NEFA-HR-2 kit (Wako, Richmond, VA) following the manufacturer's instructions. Seven standards were prepared from the supplied stock (0 to $1,000 \mu \mathrm{Eq} / \mathrm{L}$ ). Blanks, standard, and samples were run by duplicate in a 96-well microplate at $6 \mu \mathrm{L}$ per well. The inter- and intraassay CV for NEFA was 3.77 and $2.03 \%$, respectively. The microplate was incubated twice for $30 \mathrm{~min}$ after adding each of the 2 reagents. The samples were read at $550 \mathrm{~nm}$ using a Bio-Tek Microplate Reader (BioTek Instruments, Winooski, VT) with KC4 software.

Total serum calcium concentration was assessed using a commercially available assay (Calcium Liquicolor No. 0150, Stanbio Laboratory, Boerne, TX) according to the manufacturer's instructions (https://www .interchim.fr/ft/F/FT6960.pdf). Blanks, standards, and samples were run by duplicate in a 96-well microplate at $6 \mu \mathrm{L}$ per well. The inter- and intraassay CV for calcium was $4.03 \%$ and $2.29 \%$, respectively. The microplate was incubated for $1 \mathrm{~min}$ after adding the reagent. The samples were read at $550 \mathrm{~nm}$ using a Bio-Tek Microplate Reader (Bio-Tek Instruments, Winooski, VT) with KC4 software. Postpartum dams were classified as experiencing subclinical hypocalcemia when serum calcium was $\leq 2.0 \mathrm{mmol} / \mathrm{L}$ (Reinhardt et al., 2011).

\section{Assessment of Stillbirth}

Stillbirth was defined as a calf born dead or died during the first $24 \mathrm{~h}$ after parturition in dams with normal gestation length (Schuenemann et al., 2011). Stillbirth information was weekly recollected from onfarm computer records (DairyComp 305, Valley Agricultural Software, Tulare, CA). Pregnant dams with gestation length shorter and longer than $3 \mathrm{SD}$ from the mean were removed for data analyses (Vieira-Neto et al., 2017). 


\section{Assessment of LT of Prepartum Dams}

Electronic data loggers (IceQube, IceRobotics, Edinburgh, UK) were placed on the hind leg of prepartum animals to assess their LT within $14 \pm 3$ dpp. Data from individual animals were exported from IceManager software to an Excel spreadsheet (Microsoft Corp., Redmond, WA). Lying time $(\mathrm{min} / \mathrm{d}$ or $\mathrm{h} / \mathrm{d})$ and the $\mathrm{CV}$ of LT from individual dams were computed for the last 7 dpp to assess the association with blood NEFA collected at $7 \mathrm{dpp}$. The CV of LT was computed for each animal by dividing the standard deviation (SD) over LT mean within the last $7 \mathrm{dpp}$ and reported as an absolute ratio:

$$
\mathrm{CV}=\frac{\mathrm{SD}}{\mathrm{LT}}
$$

where LT is lying time for each prepartum dam for the last 7 dpp.

\section{Statistical Analyses}

Data from individual first-calf heifers and multiparous dairy cows (e.g., parity, dystocia, and stillbirth) were exported from DairyComp 305 into an Excel spreadsheet. Data pertaining to the mean LT and CV of LT for each individual prepartum animal during the $7 \mathrm{dpp}$ were summarized daily $(\mathrm{min} / \mathrm{d})$ for the analysis. Outliers were carefully investigated for each model using scatter plots and studentized residuals to avoid potential leverage or influential points. The ShapiroWilk statistic (histograms and Q-Q plots) was used to assess normality of the residuals once obtained from their respective final models.

Association of Prepartum LT, CV of LT, Serum NEFA Concentration, BCS, and Calcium Status of Dams at Calving with Stillbirth. Differences in LT, CV of LT, NEFA at $14 \pm 3$ and $7 \pm 3 \mathrm{dpp}$, $\mathrm{BCS}$ at $14 \pm 3 \mathrm{dpp}$, and calcium at calving (proportion of cows with $\leq 2.0 \mathrm{mmol} / \mathrm{L}$ ), between cows with a stillborn calf and calf born alive, were analyzed with separate individual models by parity using MIXED or GLIMMIX (binomial) procedures of SAS (version 9.4, SAS Institute Inc., Cary, NC). For each parity (firstcalf heifers or cows), a model that included season (fall, winter, spring, and summer), gestation length (short, average, or long), dystocia (yes or no), calcium status, calf sex (male or female), birth of twins (yes or no), LS, and BCS at $14 \pm 3$ dpp, was used to assess the association of variable of interests with stillbirth. Nonsignificant variables were eliminated from the model one at a time using the Wald statistic backward selection criterion $(P>0.15)$ because of their lack of effect on the outcome variable. Herd was included as a random effect. Except for stocking density and calcium status (when used as an outcome variable), the remaining variables were included in the final models. The differences in least squares means of the parameters of interest were computed by including the PDIFF option in the LSMEANS statement. The Tukey-Kramer method was used to obtain individual least squares means. Additionally, the herd $\times$ parity interaction was used to test the source of variation. Least squares means and standard errors of the means were reported. A $P$-value of $<0.05$ was considered statistically significant.

Correlations of Prepartum LT with the CV of LT and Prepartum Serum NEFA. To assess the correlation of LT (h/d) with the CV of LT within 7 dpp and the correlation of LT with serum NEFA at $7 \pm$ 3 dpp, LT was computed by hours per day (cows with $\leq 8,9,10,11,12,13,14,15$, and $\geq 16 \mathrm{~h}$ ). A model that included parity (first-calf heifers or cows), season (fall, winter, spring, and summer), herd, LS, and BCS at enrollment was used to assess the effect of LT on NEFA and the CV of LT within $7 \mathrm{dpp}$. Herd was included as a random effect and day of blood sample collection as a covariate. Then, the adjusted means by hour were plotted into an Excel spreadsheet to visualize the correlations. Additionally, the herd $\times$ parity interaction was tested. In addition, partial correlations between mean $\mathrm{CV}$ of LT within $7 \mathrm{~d}$ before blood NEFA collection at $7 \pm 3$ dpp and serum NEFA concentration at $7 \pm 3$ dpp were performed using the Pearson correlation coefficients (PROC CORR procedure of SAS). Correlations were computed by parity (lactation $=0$ and lactation $\geq 1$ ) and adjusted for the effect of herd, season, LS, and BCS at enrollment using the PARTIAL statement. A $P$-value of $<0.05$ was considered statistically significant.

\section{RESULTS}

The overall gestation length was $276 \pm 6.9 \mathrm{~d}$ and dams with shorter $(<255 \mathrm{~d})$ and longer $(>297 \mathrm{~d})$ than $3 \mathrm{SD}$ from the mean were not included in the analyses. Seven prepartum dams were excluded from the study due to gestation length, being open, or that died at or before calving. Therefore, a total of 1,044 Holstein heifers and cows were included in the final analyses. The overall proportion of stillbirth was $4.8 \%(50 / 1,044)$. Distribution of stillbirth by herd, gestation length, parity, dystocia, stocking density at $7 \pm 3 \mathrm{dpp}$, and season in Holstein dairy cows are provided in Table 2. In addition, distribution of parity by herd, season, LS at $14 \pm$ 3 dpp, mean BCS at $14 \pm 3$ dpp, mean NEFA (at $14 \pm$ 
3 and at $7 \pm 3 \mathrm{dpp}$ ), stillbirth, and hypocalcemia status in Holstein dairy cows are provided in Table 3. The mean duration of prepartum LT (min/d), CV of LT, BCS at $14 \pm 3 \mathrm{dpp}, \mathrm{NEFA}$ at $14 \pm 3$ and at $7 \pm 3 \mathrm{dpp}$, and hypocalcemia between cows with a stillborn calf or calves born alive by parity were presented (Table 4).

\section{Association of Prepartum LT with Stillbirth}

As shown in Table 4, regardless of the parity, cows with a stillborn calf had significantly lower prepartum LT during the $7 \mathrm{dpp}$ (heifers $=570 \pm 35 \mathrm{~min} / \mathrm{d}$; multiparous $=716 \pm 28 \mathrm{~min} / \mathrm{d})$ compared with cows with a calf born alive (heifers $=625 \pm 25 \mathrm{~min} / \mathrm{d}$; multiparous $=762 \pm 12 \mathrm{~min} / \mathrm{d}$ ). Regardless of parity, dams with a stillborn calf had significantly higher prepartum CV of LT during the $7 \mathrm{dpp}$ (heifers $=0.18$ and multiparous $=0.14)$ compared with dams with a calf born alive (heifers $=0.14$ and multiparous $=0.11$, respectively; Table 4).

\section{Association of Prepartum Serum NEFA Concentration, BCS, and Calcium Status of Dams at Calving with Stillbirth}

The herd $\times$ parity interactions were not significant for models assessed. Prepartum LS did not affect serum NEFA concentrations of dams at $14 \pm 3 \mathrm{dpp}(1=261 \pm$ $12,2=259 \pm 21,3=306 \pm 28 \mu \mathrm{Eq} / \mathrm{L} ; P=0.19)$ and at $7 \pm 3 \mathrm{dpp}(1=308 \pm 8,2=334 \pm 22,3=361 \pm 30$ $\mu \mathrm{Eq} / \mathrm{L} ; P=0.14]$. However, prepartum serum NEFA at $7 \pm 3$ dpp varied throughout the calendar seasons. Prepartum cows and first-calf heifers calving during the spring had higher $(338 \pm 16 \mu \mathrm{Eq} / \mathrm{L} ; P=0.018)$ serum NEFA concentration compared with winter $(288 \pm 16$ $\mu \mathrm{Eq} / \mathrm{L})$ and fall $(299 \pm 17 \mu \mathrm{Eq} / \mathrm{L})$, whereas summer $(320 \pm 16 \mu \mathrm{Eq} / \mathrm{L})$ did not differ from spring, winter, or fall. Multiparous cows with a stillborn calf had significantly higher prepartum serum NEFA concentration 7 \pm 3 dpp $(416 \mu \mathrm{Eq} / \mathrm{L})$ compared with multiparous cows with a calf born alive $(313 \mu \mathrm{Eq} / \mathrm{L} ; P<0.02$; Table 4). However, no significant differences were observed in prepartum NEFA serum concentration $7 \pm 3 \mathrm{dpp}(P$ $=0.61$ ) between first-calf heifers with a stillborn calf and heifers with a calf born alive (333 \pm 7 vs. $339 \pm$ $5 \mu \mathrm{Eq} / \mathrm{L}$ ). No significant differences were observed in BCS between cows with a stillborn calf compared with cows with a calf born alive (Table 4). Regardless of parity, the proportion of cows with hypocalcemia $(\leq 2.0$ $\mathrm{mmol} / \mathrm{L}$ ) within $48 \mathrm{~h}$ after parturition was higher for cows with a stillborn calf compared with cows with a calf born alive (Table 4 ).
Table 2. Distribution of the proportion of stillbirth by herd, parity, dystocia, stocking density, and season in Holstein dairy cows

\begin{tabular}{|c|c|c|}
\hline Item & $\begin{array}{c}\text { Stillbirth, }{ }^{1} \\
\text { no./no. ( } \%)\end{array}$ & $P$-value \\
\hline Herd & & 0.80 \\
\hline 1 & $15 / 353(4.2)$ & \\
\hline 2 & $20 / 376(5.3)$ & \\
\hline 3 & $15 / 315(4.7)$ & \\
\hline Gestation length $^{2}(\mathrm{~d})$ & & 0.06 \\
\hline $255-269$ & $7 / 86(8.1)$ & \\
\hline $270-283$ & $15 / 882(1.7)$ & \\
\hline $284-297$ & $2 / 75(2.6)$ & \\
\hline Parity $^{3}$ & & 0.55 \\
\hline Lactation $=0$ & $21 / 397(5.3)$ & \\
\hline Lactation $\geq 1$ & $29 / 647(4.4)$ & \\
\hline Dystocia $^{4}-$ & & $<0.0001$ \\
\hline Yes & $34 / 149\left(22.8^{\mathrm{a}}\right)$ & \\
\hline No & $16 / 895\left(1.8^{\mathrm{b}}\right)$ & \\
\hline Stocking density at $7 \pm 3 \mathrm{dpp}^{5}(\%)$ & & 0.52 \\
\hline$<100$ & $48 / 981(4.9)$ & \\
\hline$\geq 100$ & $2 / 63(3.2)$ & \\
\hline $\mathrm{L} \overline{\mathrm{S}}$ at $14 \pm 3 \mathrm{dpp}^{6}$ & & 0.91 \\
\hline 1 & $43 / 909(4.7)$ & \\
\hline 2 & $5 / 94(5.3)$ & \\
\hline 3 & $2 / 41(4.8)$ & \\
\hline Season & & 0.25 \\
\hline Fall & $8 / 224(3.6)$ & \\
\hline Winter & $17 / 268(6.3)$ & \\
\hline Spring & $19 / 360(5.2)$ & \\
\hline Summer & $6 / 192(3.1)$ & \\
\hline
\end{tabular}

$\overline{\mathrm{a}, \mathrm{b}}$ For each item, values $(\%)$ with different superscripts differ significantly $(P<0.05)$.

${ }^{1}$ Stillbirth was defined as a calf that was born dead or that died within $24 \mathrm{~h}$ after birth and with a normal gestation length.

${ }^{2}$ Gestation length of prepartum Holstein dairy heifers and cows was classified as average (mean $=276 \mathrm{~d}$ with a population mean $\pm 1 \mathrm{SD}$; range: 270 to $283 \mathrm{~d})$, short $($ mean $=262 \mathrm{~d}$ with $\pm 1 \mathrm{SD}$; range: 255 to $269 \mathrm{~d}$ ), or long (mean $=290$ with $\pm 1 \mathrm{SD}$; range: 284 to $297 \mathrm{~d}$ ).

${ }^{3}$ Prepartum Holstein dairy heifers were recorded as lactation $=0$ and cows as lactation $\geq 1$.

${ }^{4}$ Proportion (\%) of dams experiencing dystocia (yes or no). Dystocia was defined as a dam with a score of $\geq 2$ at calving using a 4-point scale (Schuenemann et al., 2011).

${ }^{5}$ Prepartum stocking density was calculated weekly as the ratio between number of stalls available and number of dams within the pen and multiplied by 100. Stocking density $<100 \%$ had a mean of $73.1 \%$ (ranged from 16.6 to $98.3 \%$ ). Stocking density $\geq 100 \%$ had a mean of $107 \%$ (ranged from 100 to $126 \%$ ). dpp = days prepartum.

${ }^{6}$ Locomotion score (LS) was assessed at $14 \pm 3$ dpp using a 3 -point scale with a 1 -unit increment $(1=$ sound, $2=$ mildly lame, $3=$ moderately to severely lame) as described by Amory et al. (2006).

\section{Correlations of Prepartum $L T$ with the CV of $L T$ and Prepartum Serum NEFA}

The herd $\times$ parity interactions were not significant for models assessed. Stocking density was not associated with $\mathrm{LT}(\mathrm{h} / \mathrm{d})$ or the CV of LT; only 63 dams out of 1,044 were exposed to $>100 \%$ stocking density (mean of 108\%). Prepartum heifers had higher serum NEFA concentration and lower BCS at $14 \pm 3$ dpp compared with multiparous dams (Table $3 ; P<0.001$ ). However, 
Table 3. Distribution of parity by herd, locomotion score (LS), season, mean BCS, nonesterified fatty acids (NEFA), stillbirth, and calcium status in Holstein dairy cows ${ }^{1}$

\begin{tabular}{|c|c|c|c|}
\hline Item & Lactation $=0$ & Lactation $\geq 1$ & $P$-value \\
\hline \multicolumn{4}{|l|}{ Herd no. } \\
\hline 1 & 118 & 235 & \\
\hline 2 & 143 & 233 & \\
\hline 3 & 136 & 179 & \\
\hline \multicolumn{4}{|l|}{ LS at $14 \pm 3 \mathrm{dpp}^{2}$ (no. of cows) } \\
\hline 1 & 391 & 518 & \\
\hline 2 & 2 & 92 & \\
\hline 3 & 4 & 37 & \\
\hline \multicolumn{4}{|l|}{ Season (no. of cows) } \\
\hline Fall & 66 & 158 & \\
\hline Winter & 118 & 150 & \\
\hline Spring & 145 & 215 & \\
\hline Summer & 68 & 124 & \\
\hline \multicolumn{4}{|l|}{ BCS at $14 \pm 3 \mathrm{dpp}^{3}$ (no. of cows) } \\
\hline$<2.75$ & 2 & 24 & \\
\hline$\overline{3} .0-3.5$ & 357 & 415 & \\
\hline$>3.75$ & 38 & 208 & \\
\hline Mean BCS at $14 \pm 3 \mathrm{dpp}^{3}$ & $3.37 \pm 0.01^{\mathrm{b}}$ & $3.50 \pm 0.01^{\mathrm{a}}$ & $<0.0001$ \\
\hline NEFA at $7 \pm 3 \operatorname{dpp}^{4}(\mu \mathrm{Eq} / \mathrm{L})$ & $314 \pm 12$ & $308 \pm 9$ & 0.64 \\
\hline NEFA at $14 \pm 3 \operatorname{dpp}^{4}(\mu \mathrm{Eq} / \mathrm{L})$ & $283 \pm 14^{\mathrm{a}}$ & $241 \pm 13^{\mathrm{b}}$ & 0.002 \\
\hline $\operatorname{Stillbirth}^{5}(\%)$ & 5.3 & 4.4 & 0.55 \\
\hline Hypocalcemia $\leq 2.0 \mathrm{mmol} / \mathrm{L}^{6}(\%)$ & $20.1^{\mathrm{b}}$ & $41.49^{\mathrm{a}}$ & $<0.0001$ \\
\hline \multicolumn{4}{|c|}{$\overline{\mathrm{a}, \mathrm{b}}$ Mean values $( \pm$ SEM) with different superscripts within a row differ significantly $(P<0.05)$. } \\
\hline \multirow{4}{*}{\multicolumn{4}{|c|}{$\begin{array}{l}{ }^{1} \text { Prepartum Holstein dairy heifers were recorded as lactation }=0 \text { and cows were recorded as lactation } \geq 1 . \\
{ }^{2} \text { Locomotion score }(\mathrm{LS}) \text { was assessed at } 14 \pm 3 \mathrm{~d} \text { prepartum }(\mathrm{dpp}) \text { using a } 3 \text {-point scale with a } 1 \text {-unit increment } \\
(1=\text { sound, } 2=\text { mildly lame, } 3=\text { moderately to severely lame) as described by Amory et al. (2006). } \\
{ }^{3} \text { Body condition score was assessed } 14 \pm 3 \text { dpp using a } 5 \text {-point scoring system (Ferguson et al., 1994). } \\
{ }^{4} \text { Prepartum serum NEFA concentrations were assessed at } 14 \pm 3 \text { and } 7 \pm 3 \mathrm{dpp} \text {. }\end{array}$}} \\
\hline & & & \\
\hline & & & \\
\hline & & & \\
\hline \multicolumn{4}{|c|}{$\begin{array}{l}{ }^{5} \text { Proportion of stillbirth. Stillbirth was defined as a calf that was born dead or that died within } 24 \mathrm{~h} \text { after birth } \\
\text { and with a normal gestation length. }\end{array}$} \\
\hline \multicolumn{4}{|c|}{$\begin{array}{l}{ }^{6} \text { The proportion }(\%) \text { of cows with hypocalcemia }(\leq 2.0 \mathrm{mmol} / \mathrm{L}) \text { within } 48 \mathrm{~h} \text { after parturition using total serum } \\
\text { calcium concentration (Reinhardt et al., 2011). }\end{array}$} \\
\hline
\end{tabular}

serum NEFA concentration at $7 \pm 3$ dpp did not differ by parity (Table 3 ). As prepartum dams increased their LT within $7 \mathrm{dpp}$ (from $<8.0 \mathrm{~h} / \mathrm{d}$ to $>16.0 \mathrm{~h} / \mathrm{d}$ ), the
CV of LT decreased, regardless of parity (Figure 1A). Prepartum dams had a positive quadratic association between LT by hour intervals within $7 \mathrm{~d}$ before blood

Table 4. Least squares means ( \pm SEM) of prepartum lying time (LT; mean and CV), mean BCS, nonesterified fatty acids (NEFA), and calcium status at calving on stillbirth by parity ${ }^{1}$

\begin{tabular}{|c|c|c|c|c|c|c|}
\hline Item & \multicolumn{2}{|c|}{ Lactation $=0$} & $P$-value & \multicolumn{2}{|c|}{ Lactation $\geq 1$} & $P$-value \\
\hline Mean LT within $7 \mathrm{dpp}^{2}(\min / \mathrm{d})$ & $570 \pm 35^{\mathrm{b}}$ & $625 \pm 25^{\mathrm{a}}$ & 0.02 & $716 \pm 28^{\mathrm{b}}$ & $762 \pm 12^{\mathrm{a}}$ & 0.04 \\
\hline Mean BCS at $14 \pm 3 \mathrm{dpp}^{4}$ & $3.33 \pm 0.07$ & $3.39 \pm 0.05$ & 0.21 & $3.49 \pm 0.08$ & $3.50 \pm 0.05$ & 0.95 \\
\hline NEFA at $7 \pm 3 \operatorname{dpp}^{5}(\mu \mathrm{Eq} / \mathrm{L})$ & $314 \pm 35$ & $299 \pm 22$ & 0.61 & $416 \pm 44^{\mathrm{a}}$ & $313 \pm 8^{\mathrm{b}}$ & 0.02 \\
\hline NEFA at $14 \pm 3 \operatorname{dpp}^{5}(\mu \mathrm{Eq} / \mathrm{L})$ & $280 \pm 38$ & $264 \pm 23$ & 0.62 & $326 \pm 36^{\mathrm{a}}$ & $241 \pm 14^{\mathrm{b}}$ & 0.01 \\
\hline
\end{tabular}

${ }^{\mathrm{a}, \mathrm{b}}$ Values with different superscripts within a row differ significantly $(P<0.05)$.

${ }^{1}$ Stillbirth (yes or no) was defined as a calf that was born dead or that died within $24 \mathrm{~h}$ after birth and with a normal gestation length. Prepartum Holstein dairy heifers were labeled as lactation $=0$ and cows were labeled as lactation $\geq 1$. Data were analyzed with individual models by parity using MIXED or GLIMMIX (binomial) procedures of SAS (version 9.4, SAS Institute Inc., Cary, NC).

${ }^{2}$ Mean LT was calculated as an average LT during the last $7 \mathrm{~d}$ before calving.

${ }^{3}$ Mean CV of LT was calculated as an absolute ratio between the SD on LT during the last $7 \mathrm{~d}$ before calving divided by the mean LT corresponding to the same period.

${ }^{4}$ Body condition score was assessed at $14 \pm 3$ d before calving using a 5-point scoring system (Ferguson et al., 1994).

${ }^{5}$ Prepartum serum NEFA concentration was assessed at $14 \pm 3$ and at $7 \pm 3 \mathrm{~d}$ before calving.

${ }^{6}$ The proportion (\%) of cows with hypocalcemia $(\leq 2.0 \mathrm{mmol} / \mathrm{L})$ within $48 \mathrm{~h}$ after parturition using total serum calcium concentration $($ Reinhardt et al., 2011). 
NEFA collection and serum NEFA concentrations at $7 \pm 3 \mathrm{dpp}$ for lactation $=0(P=0.02)$ and lactation $\geq 1(P=0.01$; Figure $1 \mathrm{~B})$. Prepartum dams with mean LT between 10 and $14 \mathrm{~h} / \mathrm{d}$ had the lowest serum NEFA concentration compared with dams with LT of $<8 \mathrm{~h} / \mathrm{d}$ or $>16 \mathrm{~h} / \mathrm{d}$ (Figure 1B). Prepartum pregnant heifers had an overall mild $(\mathrm{r}=0.26, P<0.001$; Figure $2 \mathrm{~A})$ and multiparous cows had an overall weak $(\mathrm{r}=$ $0.129, P=0.004$; Figure $2 \mathrm{~B}$ ) significant positive correlation between mean $\mathrm{CV}$ of LT within $7 \mathrm{~d}$ before blood NEFA collection and serum NEFA at $7 \pm 3$ dpp. The greater the CV of $\mathrm{LT}(<0.10$ vs. $>0.30)$ within $7 \mathrm{~d}$ before blood NEFA collection at $7 \pm 3 \mathrm{dpp}$, the greater the concentration of serum NEFA (302 vs. $450 \mu \mathrm{Eq} / \mathrm{L}$, respectively; $P=0.005)$. Figure 3 shows a schematic representation of 2 distinct mean LT of 2 prepartum dams within $7 \mathrm{~d}$ before blood NEFA collection at $7 \pm$ 3 dpp. On average, a prepartum dam with a CV of LT $<0.10$ displayed a more consistent daily LT with serum NEFA of $302 \mu \mathrm{Eq} / \mathrm{L}$ within $7 \mathrm{~d}$ before blood NEFA collection compared with a cow with a $\mathrm{CV}$ of $\mathrm{LT}>0.30$ and serum NEFA of $450 \mu \mathrm{Eq} / \mathrm{L}$.

\section{DISCUSSION}

The primary findings of the present study are (1) cows experiencing dystocic births had greater proportion of stillbirth, but herd, gestation length, parity, LS at enrollment, and season did not have an effect; (2) cows with a stillborn calf had reduced mean LT and increased $\mathrm{CV}$ of LT within the last $7 \mathrm{dpp}$ compared with cows with a calf born alive, regardless of parity; (3) multiparous cows with a stillborn calf had higher prepartum serum NEFA concentration compared with multiparous cows with a calf born alive, but this did not differ for first-calf heifers; (4) the proportion of postpartum dams with hypocalcemia was higher for cows and first-calf heifers with a stillborn calf compared with cows with a calf born alive; (5) there was an negative correlation between prepartum LT of dams and CV of LT (as LT increased, the CV decreased) as well as a positive correlation between prepartum dams CV of LT and serum NEFA at $7 \pm 3 \mathrm{dpp}$; and (6) prepartum dams had a positive quadratic association between LT hour intervals and serum NEFA concentration at $7 \pm$ 3 dpp.

Many risk factors have been associated with stillbirth, with the most frequently cited factors being dystocia and parity of the dam (Bicalho et al., 2007; Lombard et al., 2007; Schuenemann et al., 2011). In alignment with previous studies (Berry et al., 2007; Lombard et al., 2007; Bleul., 2011), cows experiencing dystocia at calving had more stillborn calves (Lombard et al., 2007). However, no differences were observed for parity of the dam (primiparous vs. multiparous) at calving on stillbirth in the present study. This could be, at least in part, because of dedicated efforts from all 3 dairy producers in terms of educational training to personnel on managing difficult birth (Schuenemann et al., 2011). Other studies have also reported that calves born during summer have increased odds of stillbirth compared with calves born during winter (Meyer et al., 2001; Lombard et al., 2007; Silva del Río et al., 2007). However, in the present study, we did not find a relationship between calving season and stillbirth. This could be attributed, at least in part, to a more consistent and dedicated effort during the calendar year by calving personnel or may be due to lack of statistical power. In addition, other studies that did find differences on stillbirth by season, did not report housing (Meyer et al., 2001) or were housed in dry-lot pens (Lombard et al., 2007) compared with the present study where all cows were housed in freestall barns.

On average, prepartum LT of dams was consistent with previous studies $(\sim 12 \mathrm{~h} / \mathrm{d}$; Krohn and Munksgaard, 1993; DeVries and von Keyserlingk, 2005; Jensen et al., 2005; Gomez and Cook, 2010). Our findings provide evidence that prepartum LT is an important factor associated with calf survival at parturition for both first-calf heifers and multiparous cows. Prepartum dams with reduced LT and increased CV of LT within $7 \mathrm{dpp}$ had more stillborn calves. To the best of our knowledge, this is the first study reporting an association between prepartum LT of dams and CV of LT with prepartum serum NEFA and stillbirth. Restricted prepartum LT has also been reported to negatively affect the hypothalamic-pituitary-adrenal axis activity by increasing adrenocorticotropic hormone secretion (Munksgaard and Simonsen, 1996). Also, it has been shown that as LT of cows decrease, the number of lameness cases in dairy herds increases (Galindo and Broom, 2000). As reported by Munksgaard et al. (2005), dairy cows have a strong behavioral need to rest (lying down) and it has priority over eating or social interactions. In this study, prepartum dams with a CV of LT $<0.10$ displayed a more consistent daily LT with an overall serum NEFA of $302 \mu \mathrm{Eq} / \mathrm{L}$ within $7 \mathrm{~d}$ before blood NEFA collection at $7 \pm 3$ dpp compared with cows with a $\mathrm{CV}$ of $\mathrm{LT}$ $>0.30$ and an overall serum NEFA of $450 \mu \mathrm{Eq} / \mathrm{L}$.

Interestingly, prepartum dams with increased CV of LT during the week before calving had more stillborn calves at calving compared with dams with reduced CV of LT. The observed increase on prepartum CV of LT could be driven by management or environmental factors during the prepartum period that could negatively affect their LT. According to earlier studies, many factors such as grouping of animals (comingling heifers with adult cows, dominance), overstocking (stalls and 
A

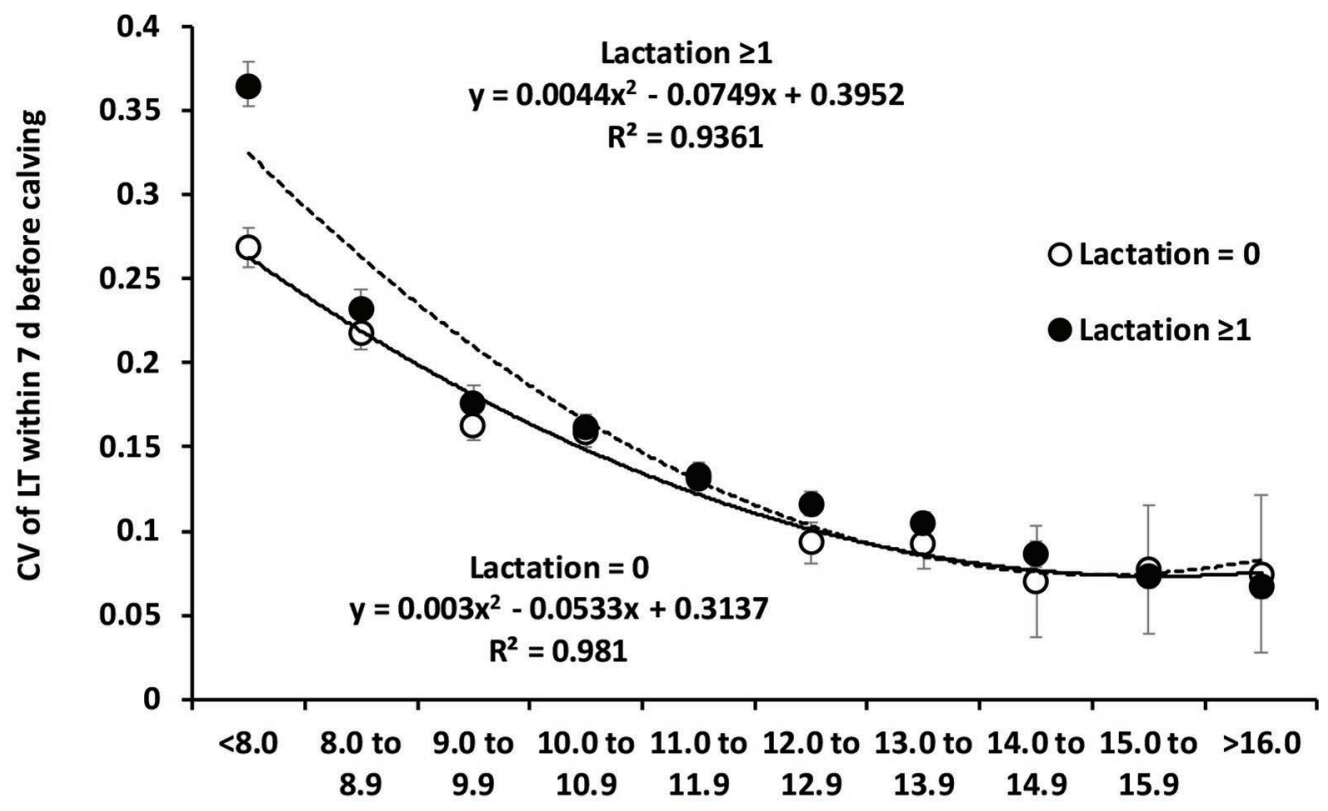

Mean lying time within $7 \mathrm{~d}$ before calving $(\mathrm{h} / \mathrm{d})$

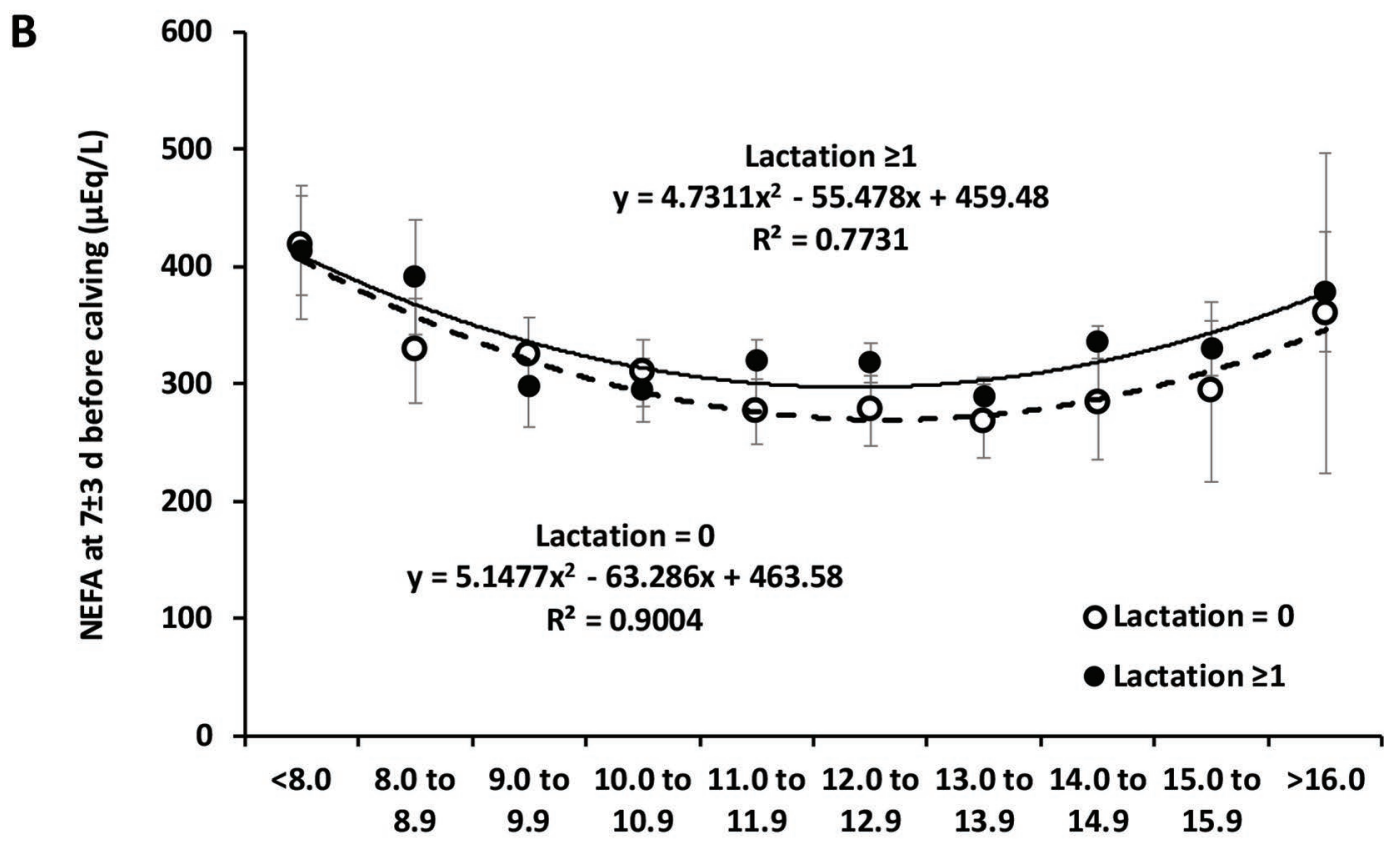

Mean lying time within $7 \mathrm{~d}$ before NEFA $(\mathrm{h} / \mathrm{d})$

Figure 1. (A) Least squares means ( \pm SEM) of lying time (LT) within 7 d prepartum (dpp) by hour intervals and the CV of LT within 7 dpp in Holstein heifers (lactation $=0$ ) and cows (lactation $\geq 1$ ). As prepartum dams increased their LT within $7 \mathrm{dpp}$, the CV of LT decreased regardless of parity. (B) Least squares means ( \pm SEM) of LT within $7 \mathrm{~d}$ before blood nonesterified fatty acid (NEFA) collection by hour intervals and serum NEFA at $7 \pm 3 \mathrm{dpp}$ in Holstein heifers (lactation $=0$ ) and cows (lactation $\geq 1$ ). Prepartum LT had a positive quadratic association with serum NEFA concentration at $7 \pm 3 \mathrm{dpp}$ for lactation $=0(P<0.02)$ and lactation $\geq 1(P<0.01)$. Blood samples were collected at $7 \pm 3$ dpp to assess serum NEFA concentration in prepartum Holstein heifers (lactation $=0$ ) and cows (lactation $\geq 1$ ). The least squares means of LT by hour intervals were obtained from the final model and plotted against the CV of LT within 7 dpp or serum NEFA at $7 \pm 3$ dpp. Each point (solid or open circles) represents the mean CV of LT within 7 dpp (A) or the mean serum NEFA at $7 \pm 3$ dpp (B) for the groups of prepartum dams within the interval of hours per day. 


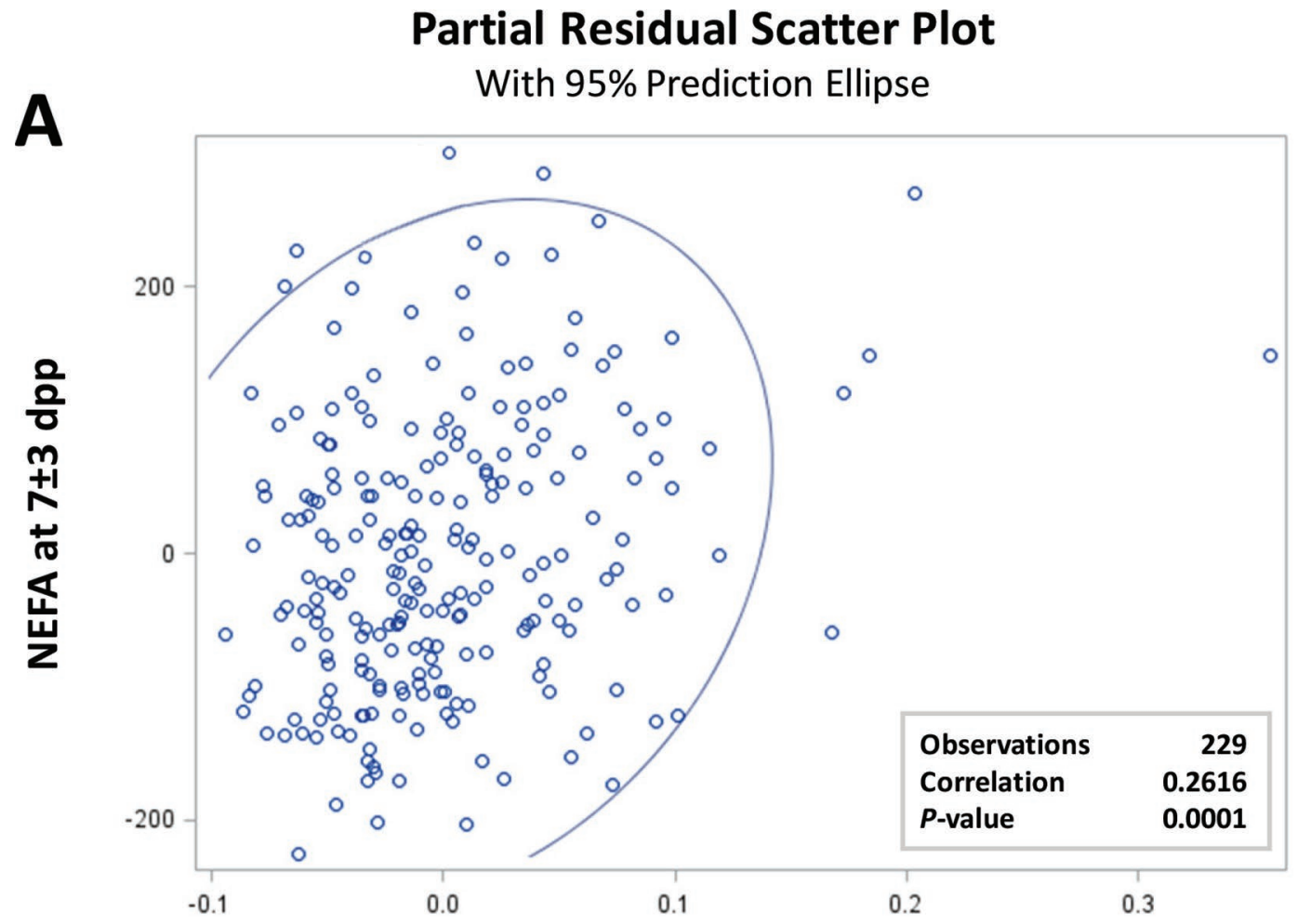

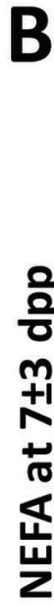

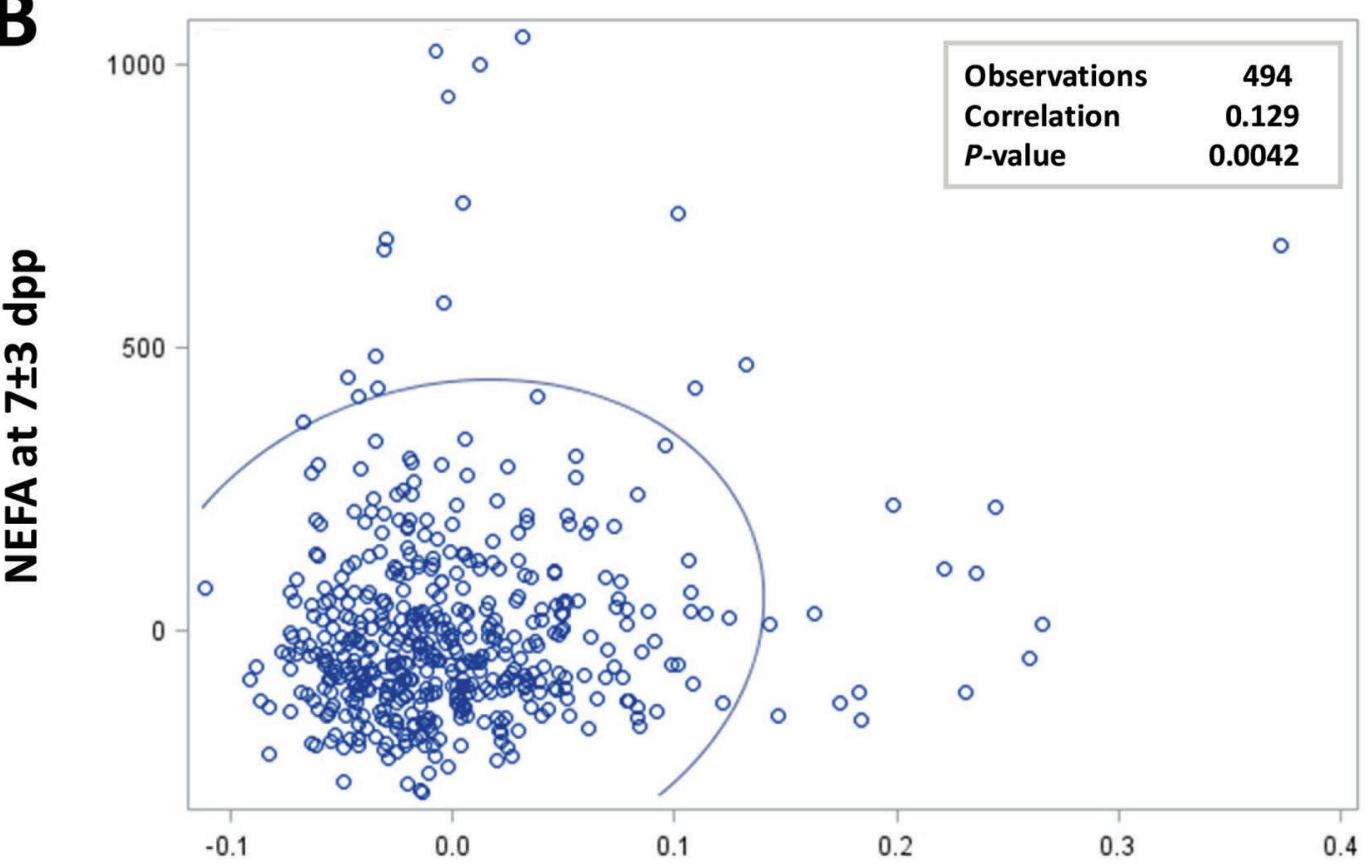

Mean CV of LT within $7 \mathrm{~d}$ before NEFA Collection

Figure 2. Partial correlations of mean CV of lying times (LT) within $7 \mathrm{~d}$ before blood nonesterified fatty acid (NEFA) collection at $7 \pm 3$ d prepartum (dpp) and serum NEFA concentration at $7 \pm 3$ dpp for Holstein heifers (A) and multiparous cows (B) adjusted by herd, parity, season, and locomotion score and BCS at enrollment. 
linear feed bunk space per cow), and facility design (e.g., stall size, bedding surface) have been significantly associated with reduced LT of cows (Galindo and Broom, 2000; Tucker et al., 2003; Fregonesi et al., 2007; Reich et al., 2010). Previous work showed that subordinate cows have a reduction of their LT with increased standing time and perching on the bed surface (Galindo and Broom, 2000). Most overstocked animals will likely have restricted access to freestalls, thus significantly reducing their LT over time (Fregonesi et al., 2007). It has been shown that cows have a preference for softer and dry freestall surfaces (sawdust or sand) compared with hard or wet surfaces (Tucker et al., 2003; Reich et al., 2010). In addition, prepartum animals are exposed to management factors such as dietary changes, pen moves, and vaccination (Grummer et al., 2004; Sepúlveda-Varas et al., 2013); however, their associations with LT and calf survival have not been fully investigated. In the present study, a negative relationship was observed between the CV of LT and LT in prepartum dairy heifers and cows, showing that dams with increased CV of LT exhibit less LT behavior compared with those with reduced CV of LT. This finding suggests that by controlling the underlying management factors associated with LT reduction could potentially improve consistency of LT over time and calf survival. Further research would need to be carried out to determine the effect of adjusting the CV of LT of prepartum dams on calf survival at calving.

The process of parturition requires energy and calcium for abdominal and uterine muscle contractions. In the present study, prepartum serum NEFA

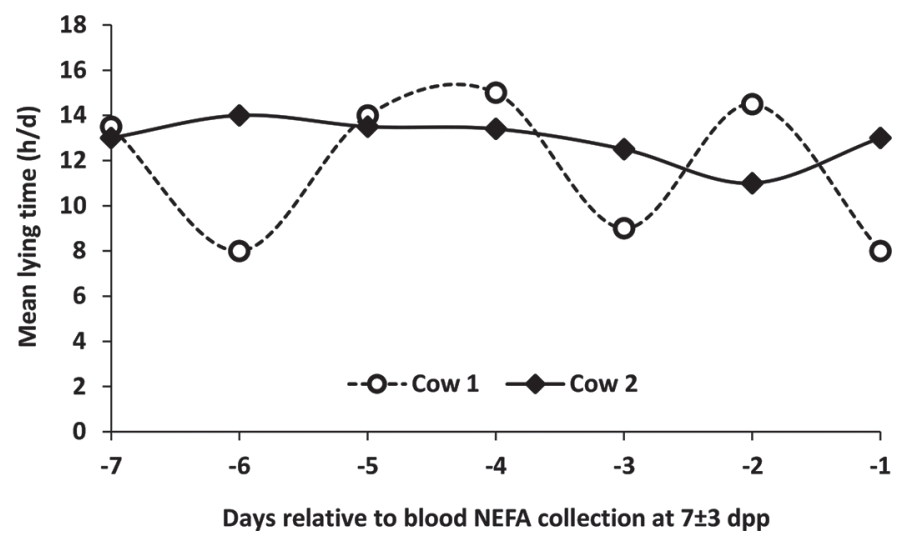

Figure 3. Schematic representation of 2 distinct mean lying times (LT; h/d) of prepartum cows $7 \mathrm{~d}$ before blood nonesterified fatty acid (NEFA) collection at $7 \pm 3$ d prepartum (dpp). Cow 1 had a mean LT of $11.71 \mathrm{~h} / \mathrm{d}$ with an $\mathrm{SD}=3.21$ and a $\mathrm{CV}=0.27$, whereas cow 2 had a mean LT of $12.91 \mathrm{~h} / \mathrm{d}$ with an $\mathrm{SD}=0.97$ and a $\mathrm{CV}=0.07$. Prepartum dams with a CV of LT $<0.10$ displayed a more consistent daily LT with serum NEFA of $302 \mu \mathrm{Eq} / \mathrm{L}$ within $7 \mathrm{~d}$ before blood NEFA collection at $7 \pm 3 \mathrm{dpp}$ compared with cows with a $\mathrm{CV}$ of $\mathrm{LT}>0.30$ and serum NEFA of $450 \mu \mathrm{Eq} / \mathrm{L}$. concentration was higher for multiparous cows with a stillborn calf. Previous studies have reported that elevated prepartum serum NEFA concentrations was a risk factor for dystocia (Dyk, 1995), retained placenta (LeBlanc et al., 2004; Ospina et al., 2010; Chapinal et al., 2011), and metritis (Ospina et al., 2010; Chapinal et al., 2011). The success of the parturition process requires the active coordination between uterine and abdominal muscle contractions. To ensure these contractions, contractile proteins contained in the muscle (actin and myosin) require adequate quantity of $\mathrm{Ca}$ and energy (ATP; Davies, 1963). The difference between the energy intake and energy requirements define the overall energy status of prepartum dams. If the energy requirement is not covered by DMI, the cow will likely compensate the deficit of energy by increasing NEFA mobilization from the adipose tissue (Adewuyi et al., 2005). In cattle, blood NEFA could be used as a source of energy by muscle (Bell, 1995) and elevated blood NEFA prepartum is an indicator of negative energy balance (Ospina et al., 2010). Another possibility for increased NEFA prepartum could be an increased inflammatory process triggered before calving by a dead fetus. These events may explain, at least in part, the increased prepartum serum NEFA concentration on multiparous cows with a stillborn calf. On the other hand, prepartum serum NEFA was not different for first-calf heifers having a stillborn or an alive calf. This declaration of nonsignificance in primiparous cows might be due to lack of statistical power. Alternatively, since first-calf heifers had lower BCS at $14 \pm 3 \mathrm{dpp}$, perhaps they did not mobilize as much NEFA as multiparous cows; therefore, prepartum energy status was not associated with stillbirth for this group of dams. In addition to the differences in prepartum BCS, first-calf heifers may require less energy for colostrum secretion compared with multiparous cows. According to Conneely et al. (2013), parity was associated with colostrum yield, where first-calf heifers produced around $5.3 \mathrm{~kg}$ of colostrum compared with multiparous cows that produce at least $7 \mathrm{~kg}$ with a maximum of $7.9 \mathrm{~kg}$ for third-lactation cows immediately after calving. The yield of $1 \mathrm{~kg}$ of colostrum requires approximately $1.1 \mathrm{Mcal}$ of $\mathrm{NE}_{\mathrm{L}}$ (McGuirk and Collins, 2004). When comparing the yield of colostrum harvested immediately after calving, the total energy requirement is about $2.86 \mathrm{Mcal}$ of $\mathrm{NE}_{\mathrm{L}}$ lower for first-calf heifers compared with multiparous cows. Therefore, this difference in energy requirement for colostrum production could explain, at least in part, the rate of NEFA mobilization in first-calf heifer before calving compared with multiparous dams.

Many factors such as reduced DMI (Dyk, 1995), increase of energy requirements, or hormonal changes before calving (Adewuyi et al., 2005) were associated with 
an increase of prepartum serum NEFA concentrations. Prepartum LT of 11 to $15 \mathrm{~h} / \mathrm{d}$ was associated with the lowest prepartum NEFA concentration and dams with either 8 to 10 or $>16 \mathrm{~h} / \mathrm{d}$ had the highest NEFA concentration. In addition, it is important to note that dams calving during the spring season had greater serum NEFA concentrations at $7 \pm 3$ dpp compared with dams calving during winter and fall, whereas summer calvings had intermediate NEFA concentrations. As mentioned earlier, DMI is one of the factors that could increase serum NEFA concentrations before calving. According to earlier studies, behavior at the feed bunk could be influenced by social dominance (DeVries et al., 2004), negatively affecting DMI. Moreover, cows could select (sorting) dietary components when feeding a TMR diet with long particle sizes (forages) at the feed bunk (Methu et al., 2001; Leonardi and Armentano, 2003). In addition, there were more births per unit of time during spring compared with fall and winter; thus, spring dams may have had to compete more at the feed bunk with the subsequent reduction of DMI and increased serum NEFA before calving. Another possibility is that increased prepartum serum NEFA during spring could be related to weather conditions (primarily due to rain). According to the Ohio Department of Natural Recourses (2011), most of the water precipitation occurs during spring and early summer. It is important to note that wheat straw and corn silage are important ingredients of prepartum diets, which could significantly change moisture content in the offered TMR. This variation in moisture content of the TMR could lead to less availability of DM delivered at the bunk, thus decreasing total DMI of prepartum dams (when diet is not adjusted for DM content during rainy days) with the subsequent increase of serum NEFA mobilization.

The dam's prepartum CV of LT within the $7 \mathrm{~d}$ before blood NEFA collection was positively correlated with prepartum serum NEFA concentrations at $7 \pm$ 3 dpp. Increased prepartum dam CV of LT may be driven by inconsistent management or variation across environmental conditions during the prepartum affecting dam's LT and DMI, thus increasing serum NEFA concentrations. Increased prepartum serum NEFA concentrations is a risk factor for dystocia (Dyk, 1995), retained placenta (LeBlanc et al., 2004; Ospina et al., 2010; Chapinal et al., 2011), and metritis (Ospina et al., 2010; Chapinal et al., 2011). Therefore, correcting the underlying causes of increased prepartum CV of LT could be a key step in reducing serum NEFA concentrations around the time of parturition, thus reducing the risk of earlier postpartum disorders. As proposed by Piñeiro et al. (2019b), the CV of LT may be a better indicator when assessing management consistency com- pared with mean LT because its ability to detect LT pattern deviations is less sensitive to animal behavioral compensations. The assessment of the prepartum CV of LT may provide dairy producers with more relevant information to understand how management at herd level can potentially affect cow behavior and use this as a tool to make management adjustments.

In addition to prepartum serum NEFA concentration, postpartum calcium status was also assessed in the present study. Regardless of parity, the proportion of cows with hypocalcemia was higher for cows with a stillborn calf compared with cows having a live-born calf. Perhaps cows with a stillborn calf may also have a lack of calcium at parturition that could negatively affect their capability to ensure adequate uterine and muscle contractions during the active phase of labor. Elevated serum cortisol decreased gut calcium absorption and bone calcium resorption (Horst and Reinhardt, 1983; White and Porterfield, 2012). It was shown that dams experiencing dystocia at calving had increased serum cortisol when compared with dams that did not experience dystocia at calving (Civelek et al., 2008; Vannucchi et al., 2015). In the present study, dams experiencing dystocic births had a greater proportion of stillbirth. It could be possible that increased cortisol of prepartum dams may decrease calcium absorption from the gut and calcium resorption from the bone. Another possible explanation is that prepartum dams with increased serum NEFA may have reduced DMI (e.g., feed availability within reach at the bunk) and spend more time standing, and thus, increased calcium demand to support lipomobilization (act as a cofactor for enzyme reactions; Reid et al., 1986). These prepartum distresses could explain, at least in part, the association of hypocalcemia with a stillborn calf compared with dams having a live-born calf.

Additional limitations of our study include not measuring other biomarkers of energy balance such as glucose or insulin, not assessing bedding management, consistency of TMR delivery and feed availability within reach of animals, sudden changes in stocking density, and weather conditions (e.g., rain) to be able to assess other types of variation in addition to daily LT and CV of LT during the entire prepartum period. Perhaps these factors directly or indirectly are associated with increased weekly variation of prepartum LT (e.g., rain would likely change the DM content of corn silage; thus, increasing the risk for an empty feed bunk if this is not adjusted accordingly) negatively affecting the transition of prepartum cows into the onset of lactation. These critical areas of management (feed availability at the bunk, bedding surface, overstocking, frequent cow moves, or sudden changes in DM of feed ingredients due to rain) need further investigation 
because of their implications on calf and cow survival during the transition period.

\section{CONCLUSIONS}

These findings showed that prepartum dairy dams with reduced LT and increased CV of LT within $7 \mathrm{dpp}$ had increased serum NEFA and reduced calf survival at calving. Prepartum dams, regardless of parity, had a positive correlation between the CV of LT within 7 $\mathrm{d}$ before blood NEFA collection with prepartum serum NEFA concentrations at $7 \pm 3 \mathrm{dpp}$. These findings suggest that consistency of LT (measured as CV of LT) is associated with maintenance of low blood NEFA concentration as prepartum dams near parturition and calf survival at calving. When troubleshooting poor calf survival at calving is undertaken, animal- and herdlevel factors associated with the consistency of LT of prepartum dams should also be assessed to improve the overall welfare of animals.

\section{ACKNOWLEDGMENTS}

The authors thank the farm owners and their staff for providing the animals used in this study and their assistance during the project. This project was partially supported by Veterinary Extension at The Ohio State University, College of Veterinary Medicine. The authors have not stated any conflicts of interest.

\section{REFERENCES}

Adewuyi, A. A., E. Gruys, and F. J. C. M. van Eerdenburg. 2005. Non esterified fatty acids (NEFA) in dairy cattle. A review. Vet. Q. 27:117-126. https://doi.org/10.1080/01652176.2005.9695192.

Amory, J. R., P. Kloosterman, Z. E. Barker, J. L. Wright, R. W. Blowey, and L. E. Green. 2006. Risk factors for reduced locomotion in dairy cattle on nineteen farms in The Netherlands. J. Dairy Sci. 89:1509-1515. https://doi.org/10.3168/jds.S0022-0302(06)72218 -4 .

Bell, A. W. 1995. Regulation of organic nutrient metabolism during transition from late pregnancy to early lactation. J. Anim. Sci. 73:2804-2819. https://doi.org/10.2527/1995.7392804x.

Berry, D. P., J. M. Lee, K. A. Macdonald, and J. R. Roche. 2007. Body condition score and body weight effects on dystocia and stillbirths and consequent effects on postcalving performance. J. Dairy Sci. 90:4201-4211. https://doi.org/10.3168/jds.2007-0023.

Bicalho, R. C., K. N. Galvão, S. H. Cheong, R. O. Gilbert, L. D. Warnick, and C. L. Guard. 2007. Effect of stillbirths on dam survival and reproduction performance in Holstein dairy cows. J. Dairy Sci. 90:2797-2803. https://doi.org/10.3168/jds.2006-504.

Bleul, U. 2011. Risk factors and rates of perinatal and postnatal mortality in cattle in Switzerland. Livest. Sci. 135:257-264. https://doi .org/10.1016/j.livsci.2010.07.022.

Chapinal, N., M. Carson, T. F. Duffield, M. Capel, S. Godden, M. Overton, J. E. P. Santos, and S. J. LeBlanc. 2011. The association of serum metabolites with clinical disease during the transition period. J. Dairy Sci. 94:4897-4903. https://doi.org/10.3168/jds $.2010-4075$
Civelek, T., H. A. Celik, G. Avci, and C. C. Cingi. 2008. Effects of dystocia on plasma cortisol and cholesterol levels in Holstein heifers and their newborn calves. Bull. Vet. Inst. Pulawy 52:649-654.

Conneely, M., D. P. Berry, R. Sayers, J. P. Murphy, I. Lorenz, M. L. Doherty, and E. Kennedy. 2013. Factors associated with the concentration of immunoglobulin G in the colostrum of dairy cows. Animal 7:1824-1832. https://doi.org/10.1017/S1751731113001444.

Dann, H. M., N. B. Litherland, J. P. Underwood, M. Bionaz, A. D'Angelo, J. W. McFadden, and J. K. Drackley. 2006. Diets during far-off and close-up dry periods affect periparturient metabolism and lactation in multiparous cows. J. Dairy Sci. 89:3563-3577. https://doi.org/10.3168/jds.S0022-0302(06)72396-7.

Davies, R. E. 1963. A molecular theory of muscle contraction: Calcium-dependent contractions with hydrogen bond formation plus ATP-dependent extensions of part of the myosin-actin cross-bridges. Nature 199:1068-1074. https://doi.org/10.1038/1991068a0.

DeVries, T. J., and M. A. G. von Keyserlingk. 2005. Time of feed delivery affects the feeding and lying patterns of dairy cows. J. Dairy Sci. 88:625-631. https://doi.org/10.3168/jds.S0022-0302(05)72726 -0 .

DeVries, T. J., M. A. G. von Keyserlingk, and D. M. Weary. 2004. Effect of feeding space on the inter-cow distance, aggression, and feeding behavior of free-stall housed lactating dairy cows. J. Dairy Sci. 87:1432-1438. https://doi.org/10.3168/jds.S0022 -0302(04)73293-2.

Drackley, J. K., and F. C. Cardoso. 2014. Prepartum and postpartum nutritional management to optimize fertility in high-yielding dairy cows in confined TMR systems. Animal 8(Suppl. 1):5-14. https:// doi.org/10.1017/S1751731114000731.

Dyk, P. B. 1995. The association of prepartum non-esterified fatty acids and body condition with peripartum health problems on 95 Michigan dairy farms. MS Thesis. Department of Animal Science, Michigan State University, East Lansing.

Ferguson, J. D., D. T. Galligan, and N. Thomsen. 1994. Principal descriptors of body condition score in Holstein cows. J. Dairy Sci 77:2695-2703. https://doi.org/10.3168/jds.S0022-0302(94)77212 $-\mathrm{X}$.

Fregonesi, J. A., C. B. Tucker, and D. M. Weary. 2007. Overstocking reduces lying time in dairy cows. J. Dairy Sci. 90:3349-3354. https: //doi.org/10.3168/jds.2006-794.

Galindo, F., and D. M. Broom. 2000. The relationships between social behaviour of dairy cows and the occurrence of lameness in three herds. Res. Vet. Sci. 69:75-79. https://doi.org/10.1053/rvsc.2000 .0391 .

Gomez, A., and N. B. Cook. 2010. Time budgets of lactating dairy cattle in commercial freestall herds. J. Dairy Sci. 93:5772-5781. https://doi.org/10.3168/jds.2010-3436.

Grummer, R. R. 1995. Impact of changes in organic nutrient metabolism on feeding the transition dairy cow. J. Anim. Sci. 73:28202833. https://doi.org/10.2527/1995.7392820x.

Grummer, R. R., D. G. Mashek, and A. Hayirli. 2004. Dry matter intake and energy balance in the transition period. Vet. Clin. North Am. Food Anim. Pract. 20:447-470. https://doi.org/10.1016/j .cvfa.2004.06.013.

Gundelach, Y., K. Essmeyer, M. K. Teltscher, and M. Hoedemaker. 2009. Risk factors for perinatal mortality in dairy cattle: cow and foetal factors, calving process. Theriogenology 71:901-909. https:/ /doi.org/10.1016/j.theriogenology.2008.10.011.

Horst, R. L., and T. A. Reinhardt. 1983. Vitamin D metabolism in ruminants and its relevance to the periparturient cow. J. Dairy Sci. 66:661-678. https://doi.org/10.3168/jds.S0022-0302(83)81844-X.

Jensen, M. B., L. J. Pedersen, and L. Munksgaard. 2005. The effect of reward duration on demand functions for rest in dairy heifers and lying requirements as measured by demand functions. Appl. Anim. Behav. Sci. 90:207-217. https://doi.org/10.1016/j.applanim 2004.08.006.

Krohn, C. C., and L. Munksgaard. 1993. Behaviour of dairy cows kept in extensive (loose housing/pasture) or intensive (tie stall) environments II. Lying and lying-down behaviour. Appl. Anim. Behav. Sci. 37:1-16. https://doi.org/10.1016/0168-1591(93)90066-X. 
LeBlanc, S. J., T. H. Herdt, W. M. Seymour, T. F. Duffield, and K. E. Leslie. 2004. Peripartum serum Vitamin E, retinol, and beta-carotene in dairy cattle and their associations with disease. J. Dairy Sci. 87:609-619. https://doi.org/10.3168/jds.S0022-0302(04)73203 -8 .

Leonardi, C., and L. E. Armentano. 2003. Effect of quantity, quality, and length of alfalfa hay on selective consumption by dairy Cows. J. Dairy Sci. 86:557-564. https://doi.org/10.3168/jds.S0022 -0302(03)73634-0.

Lombard, J. E., F. B. Garry, S. M. Tomlinson, and L. P. Garber. 2007. Impacts of dystocia on health and survival of dairy calves. J. Dairy Sci. 90:1751-1760. https://doi.org/10.3168/jds.2006-295.

Martiskainen, P., M. Järvinen, J. P. Skön, J. Tiirikainen, M. Kolehmainen, and J. Mononen. 2009. Cow behaviour pattern recognition using a three-dimensional accelerometer and support vector machines. Appl. Anim. Behav. Sci. 119:32-38. https://doi.org/10 .1016/j.applanim.2009.03.005.

McGuirk, S. M., and M. Collins. 2004. Managing the production, storage, and delivery of colostrum. Vet. Clin. North Am. Food Anim. Pract. 20:593-603. https://doi.org/10.1016/j.cvfa.2004.06.005.

Methu, J. N., E. Owen, A. L. Abate, and J. C. Tanner. 2001. Botanical and nutritional composition of maize stover, intakes and feed selection by dairy cattle. Livest. Prod. Sci. 71:87-96. https://doi .org/10.1016/S0301-6226(01)00212-3.

Meyer, C. L., P. J. Berger, K. J. Koehler, J. R. Thompson, and C. G. Sattler. 2001. Phenotypic trends in incidence of stillbirth for Holsteins in the United States. J. Dairy Sci. 84:515-523. https:// doi.org/10.3168/jds.S0022-0302(01)74502-X.

Munksgaard, L., M. B. Jensen, L. J. Pedersen, S. W. Hansen, and L. Matthews. 2005. Quantifying behavioural priorities - effects of time constraints on behaviour of dairy cows, Bos taurus. Appl. Anim. Behav. Sci. 92:3-14. https://doi.org/10.1016/j.applanim .2004.11.005.

Munksgaard, L., and H. B. Simonsen. 1996. Behavioral and pituitary adrenal-axis responses of dairy cows to social isolation and deprivation of lying down. J. Anim. Sci. 74:769-778. https://doi.org/10 $.2527 / 1996.744769 x$.

National Research Council. 2001. Nutrient Requirements of Dairy Cattle. 7th rev. ed. Natl. Acad. Press, Washington, DC.

Ohio Department of Natural Recourses. 2011. Division of soil and water resources. Precipitation in Ohio. Accessed Mar. 15, 2020. https: //water.ohiodnr.gov/portals/soilwater/pdf/inventory/fctsht11 .pdf.

Ospina, P. A., D. V. Nydam, T. Stokol, and T. R. Overton. 2010. Evaluation of nonesterified fatty acids and $\beta$-hydroxybutyrate in transition dairy cattle in the northeastern United States: Critical thresholds for prediction of clinical diseases. J. Dairy Sci. 93:546554. https://doi.org/10.3168/jds.2009-2277.

Philipsson, J., J. L. Foulley, J. Lederer, T. Liboriussen, and A. Osinga. 1979. Sire evaluation standards and breeding strategies for limiting dystocia and stillbirth. Report of an E.E.C./E.A.A.P. working group. Livest. Prod. Sci. 6:111-127. https://doi.org/10.1016/0301 -6226(79)90013-7.

Piñeiro, J. M., B. T. Menichetti, A. A. Barragan, A. E. Relling, W. P. Weiss, S. Bas, and G. M. Schuenemann. 2019a. Associations of pre- and postpartum lying time with metabolic, inflammation, and health status of lactating dairy cows. J. Dairy Sci. 102:3348-3361. https://doi.org/10.3168/jds.2018-15386.

Piñeiro, J. M., B. T. Menichetti, A. A. Barragan, A. E. Relling, W. P. Weiss, S. Bas, and G. M. Schuenemann. 2019b. Associations of postpartum lying time with culling, milk yield, cyclicity, and reproductive performance of lactating dairy cows. J. Dairy Sci. 102:3362-3375. https://doi.org/10.3168/jds.2018-15387.

Reich, L. J., D. M. Weary, D. M. Veira, and M. A. G. von Keyserlingk. 2010. Effects of sawdust bedding dry matter on lying behavior of dairy cows: A dose-dependent response. J. Dairy Sci. 93:15611565. https://doi.org/10.3168/jds.2009-2713.

Reid, I. M., C. J. Roberts, R. J. Treacher, and L. A. Williams. 1986. Effect of body condition at calving on tissue mobilization, development of fatty liver and blood chemistry of dairy cows. Anim. Prod. 43:7-15. https://doi.org/10.1017/S0003356100018298.

Reinhardt, T. A., J. D. Lippolis, B. J. McCluskey, J. P. Goff, and R. L. Horst. 2011. Prevalence of subclinical hypocalcemia in dairy herds. Vet. J. 188:122-124. https://doi.org/10.1016/j.tvjl.2010.03.025.

Rorie, R. W., T. R. Bilby, and T. D. Lester. 2002. Application of electronic estrus detection technologies to reproductive management of cattle. Theriogenology 57:137-148. https://doi.org/10.1016/ S0093-691X(01)00663-X.

Schuenemann, G. M., I. Nieto, S. Bas, K. N. Galvão, and J. Workman. 2011. Assessment of calving progress and reference times for obstetric intervention during dystocia in Holstein dairy cows. J. Dairy Sci. 94:5494-5501. https://doi.org/10.3168/jds.2011-4436.

Sepúlveda-Varas, P., J. M. Huzzey, D. M. Weary, and M. A. G. Von Keyserlingk. 2013. Behaviour, illness and management during the periparturient period in dairy cows. Anim. Prod. Sci. 53:988-999. https://doi.org/10.1071/AN12286.

Silva del Río, N., S. Stewart, P. Rapnicki, Y. M. Chang, and P. M. Fricke. 2007. An observational analysis of twin births, calf sex ratio and calf mortality in Holstein dairy cattle. J. Dairy Sci. 90:12551264. https://doi.org/10.3168/jds.S0022-0302(07)71614-4.

Stangaferro, M. L., R. Wijma, L. S. Caixeta, M. A. Al-Abri, and J. O. Giordano. 2016. Use of rumination and activity monitoring for the identification of dairy cows with health disorders: Part I. Metabolic and digestive disorders. J. Dairy Sci. 99:7395-7410. https:// doi.org/10.3168/jds.2016-10907.

Tucker, C. B., D. M. Weary, and D. Fraser. 2003. Effects of three types of free-stall surfaces on preferences and stall usage by dairy cows. J. Dairy Sci. 86:521-529. https://doi.org/10.3168/jds.S0022 -0302(03)73630-3.

Vannucchi, C. I., J. A. Rodrigues, L. C. G. Silva, C. F. Lúcio, G. A. L. Veiga, P. V. Furtado, C. A. Oliveira, and M. Nichi. 2015. Association between birth conditions and glucose and cortisol profiles of periparturient dairy cows and neonatal calves. Vet. Rec. 176:358. https://doi.org/10.1136/vr.102862.

Vázquez Diosdado, J. A., Z. E. Barker, H. R. Hodges, J. R. Amory, D. P. Croft, N. J. Bell, and E. A. Codling. 2015. Classification of behaviour in housed dairy cows using an accelerometer-based activity monitoring system. Anim. Biotelem. 3:15. https://doi.org/ 10.1186/s40317-015-0045-8.

Vieira-Neto, A., K. N. Galvão, W. W. Thatcher, and J. E. P. Santos. 2017. Association among gestation length and health, production, and reproduction in Holstein cows and implications for their offspring. J. Dairy Sci. 100:3166-3181. https://doi.org/10.3168/jds .2016-11867.

White, B., and S. Porterfield. 2012. Endocrine and Reproductive Physiology. 4th ed. Mosby Physiology Monograph Series. Elsevier Health Sciences, Philadelphia, PA.

\section{ORCIDS}

J. M. Piñeiro @ https://orcid.org/0000-0002-5212-3817

A. A. Barragan ( $\bullet$ https://orcid.org/0000-0003-0678-8356

A. E. Relling ๑ https://orcid.org/0000-0002-1288-3037

A. Garcia-Guerra (ㄴ) https://orcid.org/0000-0002-4114-5965

G. M. Schuenemann (ㄴ) https://orcid.org/0000-0003-1114-4512 